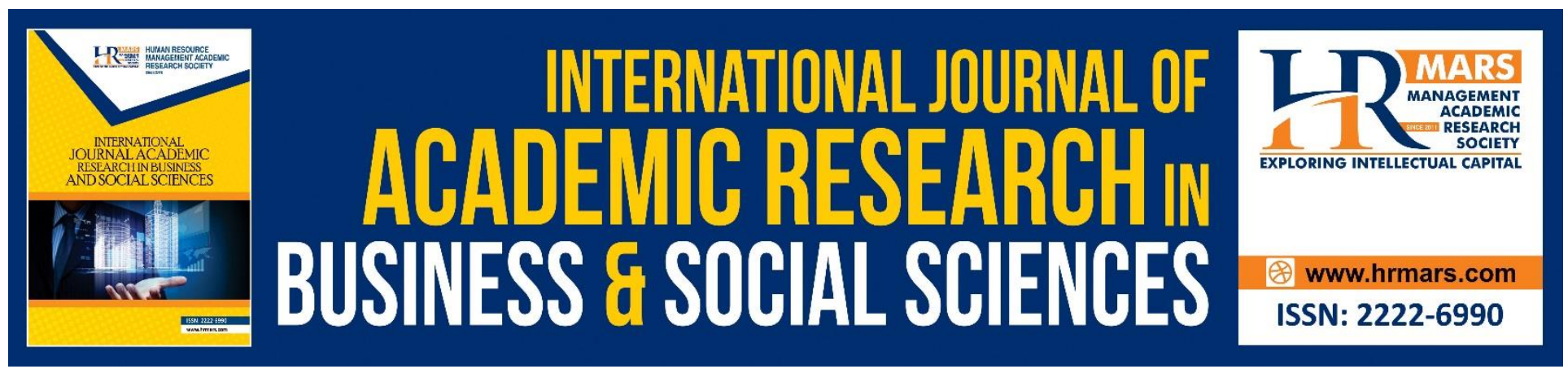

\title{
Electronic Tagging as a Crime Control Model in Malaysia: A Way Forward
}

\section{Che Audah Hassan}

To Link this Article: http://dx.doi.org/10.6007/IJARBSS/v8-i11/4947

DOI: $10.6007 /$ IJARBSS/v8-i11/4947

Received: 06 Oct 2018, Revised: 29 Oct 2018, Accepted: 21 Nov 2018

Published Online: 28 Nov 2018

In-Text Citation: (Hassan, 2018)

To Cite this Article: Hassan, C. A. (2018). Electronic Tagging as a Crime Control Model in Malaysia: A Way Forward. International Journal of Academic Research in Business and Social Sciences, 8(11), 698-710.

Copyright: (C) 2018 The Author(s)

Published by Human Resource Management Academic Research Society (www.hrmars.com)

This article is published under the Creative Commons Attribution (CC BY 4.0) license. Anyone may reproduce, distribute, translate and create derivative works of this article (for both commercial and non-commercial purposes), subject to full attribution to the original publication and authors. The full terms of this license may be seen at: http://creativecommons.org/licences/by/4.0/legalcode

Vol. 8, No. 11, 2018, Pg. 698 - 710

http://hrmars.com/index.php/pages/detail/IJARBSS

JOURNAL HOMEPAGE

Full Terms \& Conditions of access and use can be found at http://hrmars.com/index.php/pages/detail/publication-ethics 


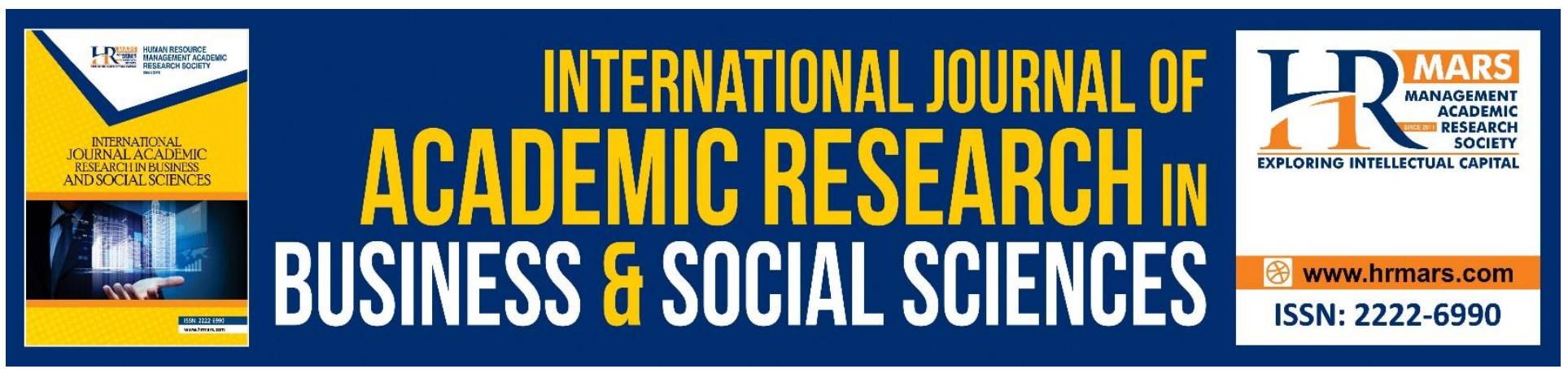

\title{
Electronic Tagging as a Crime Control Model in Malaysia: A Way Forward
}

\author{
Che Audah Hassan \\ Faculty of Law, Universiti Teknologi MARA, Shah Alam, Selangor, Malaysia \\ Email: audah@salam.uitm.edu.my
}

\begin{abstract}
The aim of electronic tagging in Malaysia can be divided into two, a tool for monitoring under the preventive laws such as the Prevention of Crime Act 1959 (POCA), Prevention of Terrorism Act 2015 (POTA) and a substitution for bail pending trial and appeal. Arguably, under the POCA 1959 and POTA 2015, the ordinary criminal procedures prescribed under Criminal Procedure Code is not fully applicable, and there are special procedures provided for the disposal of cases which upon conviction, could lead to attachment of an electronic monitoring device (EMD) to the body of the person. The consequences of a conviction under these Acts are; registration of the name in the Register of Criminal, subject to police supervision with the attachment of EMD (with or without house curfew) and worst, detention. In this paper, the authors will analyze the special procedures under POCA and POTA in line with the aim of controlling crime and highlight the possible issues which may arise concerning fundamental liberty of the person ordered to be attached with tagging as well as right to fair and public hearing under Article 10 of Universal Declaration of Human Rights and natural justice.
\end{abstract}

Keywords: Electronic Tagging, Crime-Control, Liberty, Justice, Inquiry Officer, Police Supervision

\section{INTRODUCTION}

In Malaysia, there were few legislation dealing with the dangerous criminals such as Internal Security Act 1960, Restricted Resident Act 1933, Banishment Act 1959 and Emergency (Public Order and Crime Prevention) Ordinance 1969. On the $15^{\text {th }}$ of September 2011, the Prime Minister of Malaysia announced for the repeal of the said laws. With the abolition of those Acts, a total number of 9,095 criminals detained under the repealed laws were released (Ahmad Zahid bin Hamidi, 2013). An analysis conducted by Royal Malaysian Police indicated that 18 months after the abolish of 1969 and 1933 Act, crime index rate for offences such as murder, gang robbery, and use of force or threat had increased (Ahmad Zahid bin Hamidi, 2013). Treating public security as essential, thus controlling crime becomes crucial, some actions were initiated by the government including the introduction of electronic tagging (officially known as electronic monitoring) under the preventive laws. 


\section{METHODOLOGY}

This article employs a qualitative legal research. It encompasses a doctrinal analysis in which the method of qualitative data collection will be conducted by collecting information from primary legal sources in the form of legislative texts comprising of statutes, codes and regulations. The review of primary sources include the Prevention of Crime Act 1959, Prevention of Crime (Amendment and Extension) 2014 and Prevention Of Terrorism Act 2015. This method of qualitative primary data collection was also conducted through semi structured interviews with three Monitoring Officer at headquarter in Bukit Aman as well as two Police Officer in charge at Police Station, two Inquiry Officers, one Deputy Public Prosecutor and the Chairman of Board for Prevention of Crime and Terrorism and two persons who are on tagging.

Apart from that, secondary legal sources from Hansards, law text books, law journals and law committee reports were also collected. In addition, the literature in the field of social sciences comprising of academic publications and non academic publications such as newspapers reports and websites were also collected.

\section{DISCUSSION}

\section{Definition of EMD}

Electronic tagging (electronic monitoring) requires an offender or a person to wear an electronic monitoring device (EMD) consists of a strap, a smart tag, and a beacon, assembled and strapped together at the offender's right or left leg. The EMD sends a signal to a central monitoring unit by way of GPS. The EMD weight about 200 gram could not be removed without permission from the authority. Any attempt to tamper or remove the EMD is an offence by itself. Consequently, by fitting an EMD to a person's body will enable the authority to track his location and movement.

The fitting of EMD on a body of a person may raise concern on fundamental liberty such as right to privacy of the person tagged.In addition, the procedures provided for the order of fitting the EMD should be in consistent with natural justice, This concern therefore, creates an interest to study on the laws relating to electronic tagging or monitoring.

\section{Preventive laws}

Currently, there are four preventive laws in Malaysia which apply EMD namely; Prevention of Crime Act 1959 (POCA), Prevention of Terrorism Act 2015 (POTA), Security Offences (Special Measures) Act 2012 (SOSMA), and Dangerous Drugs (Special Preventive Measures) (Amendment) Act 2015 (DDA). The analysis of the procedures in this paper is only related to POCA and POTA due to similarities in processes. POCA was in existence since 1959, but the provisions were enhanced by an amendment in 2014 through Prevention of Crime (Amendment and Extension) 2014, to insert provisions on the attachment of EMD as well as the extensive application to the state of Sabah and Sarawak. POCA applies to a wide category of offences (known as registrable categories) which under the first category, it involves unlawful and secret society whereby several persons committing the offence punishable under the Penal Code. Secondly, it applies to an individual offender who commits an offence relating to trafficking in dangerous drugs or lives on the proceeds of the drug; trafficking in persons or live on the proceeds; unlawful gaming; smuggler of migrant; a person who recruit others to be a member of secret society; and a person who engaged or support of terrorism acts. On the 
other hand, POTA deals with acts of terrorism, the commission or support of terrorist which include listed terrorist organizations in a foreign country or any part of a foreign country, and for the control of persons engaged in such acts and for related matters. Under POCA and POTA, the particulars of persons convicted would be recorded in the Register of Criminals. Register of Criminals is a document containing names and particulars of criminals. The register is kept by a Registrar of Criminals appointed under section 3 of the Registration of Criminals \& Undesirable Persons Act 1969. The purpose of Register of Criminals is to assist the police to monitor the activities of those registered in maintaining public safety.

\section{Models of a criminal justice system}

There are a few models available for criminal justice system, and the most notable one is the Crimecontrol model (CCM) and Due Process model (DPM) introduced by Packer (1964). The CCM has based on the proposition that repression of criminal conduct is the most critical function to be performed by the criminal process. The failure to suppress crime causes the breakdown of public order in which society has an interest. To achieve crime control, this model emphasizes that the system must be efficient, Efficiency may be achieved by way of speed and finality. Thus the process of apprehending, trying, convicting and sanctioning a criminal offender must have the element of speed and finality. To expedite the process, Packer suggested that the procedures have to be informal with fewer restrictions on the administrative fact-finding.

In comparison to CCM, DPM places heavy reliance on the primacy of the individual and the complementary concept of limitation on official power. This model does not totally rely on the administrative process in criminal justice. Hence, there should be a check and balance on the exercise of power by the police and the rights of the accused by way of an adversarial trial.

\section{Criminal Justice System in Malaysia}

Preventive laws were enacted under Article 149 of Federal Constitution. Article 149, grant special powers to the Parliament in dealing with subversion, organized violence acts and crimes prejudicial to the public. In general, it seems that Malaysia subscribes to the CCM. However, the authority took the effort to take into account the accused rights, whenever possible.

\section{Analysis of Procedures in POCA and POTA}

The criminal procedures applicable in cases of crime is governed by the Criminal Procedure Code (CPC) starting from the date of arrest until the finding of the decision by a court of law. Under ordinary procedures, the prosecution of the case would be conducted by the Public Prosecutor or other officers upon obtaining his consent. The accused who is represented by a legal counsel will have the opportunity to attend and defend his case in court until the final judgment. The maximum period of remand allowed is seven or fourteen days on two application, depending on the offence charged.

In POCA and POTA, the ordinary procedures under CPC is not entirely applicable. There are special procedures prescribed starting from the date of arrest until its final decision by the Board of Prevention of Crime or Board of Prevention of Terrorism. At the beginning of the investigation, a police officer may, without a warrant, arrest any person if he has reason to believe that grounds exist which would justify the holding of an inquiry. The purpose of an inquiry is to determine whether there 
are reasonable grounds for believing that the person is a member of any registrable categories i.e involvement with offences listed under POCA and POTA respectively. The person arrested should be taken before a Magistrate, and he could be remanded for fifty-nine (59) days on two application to the Magistrate. The first application is by the police officer not below the rank of Inspector (for 21 days) and the second application of remand (38 days) is by the Public Prosecutor. During this period of 59 days, the case will be submitted to the Inquiry Officer whose duty is to check the report filed by the police, whether to affirm or reverse the police finding relating to the involvement of the person subject to inquiry in any of the listed offences under the registrable categories. The inquiry finding then, is submitted to the Board. The Board will look into the case for adjudication based on reports of Inquiry Officer and police. The decision made by the Board is binding on that person.

Apparently, the characteristic of crime control model of a criminal justice system in Malaysia seems consistent with what Packer had prescribed for the crime control model to be achievable. The element of speed could be seen from the fact that the procedures for the determination of this case were diverted from an ordinary process whereby, the role of Inquiry officer takes place and the administrative adjudication by Board of Prevention of Crime or Board of Prevention of Terrorism. The existence of circumstances to avoid trial in court of law will expedite the process of disposal of this case by way of the administrative body. In POCA and POTA, the whole process is done within 59 days of remand (exclusive of time to appeal) in contrast to the indefinite length of the period when involved trial in court. Besides, the strict rules of evidence and standard of proof beyond reasonable doubt will not be applicable for POCA and POTA.

Although the objective of crime control was targeted, it does not mean authority ignores the rights of the person arrested under both Acts of preventive laws. The appointment of Inquiry Officer to investigate the case, is a check and balance on the report of investigation prepared by a police officer. Inquiry Officer is an independent officer appointed under the Ministry of Home Affairs and must not be a police officer. In addition, the existence of Board members, consisting of a Chairman, a person who shall be a legally qualified person with at least fifteen years experience in the legal field is another element for check and balance. The Chairman and other members of Board are appointed by the Yang Dipertuan Agong (the Royal Highness) and not by the Prime Minister. This form of check and balance will ensure the reliability of the decision made despite the absence of judge in a court of law.

\section{Advantages of POCA and POTA}

The benefits of POCA and POTA lies in the fact that, sometimes there are obstacles in securing a conviction in the court of law according to ordinary criminal procedures in cases involving more than one offender. In 2017, Kwang commented that POTA, the new anti-terror laws enable the government to track and capture individuals whose actions would probably not get caught within the traditional criminal law provisions. Some illustrations on POCA cases, will facilitate understanding.

Firstly, a problem in getting an accomplice agreeing to testify against co-accused. Secondly, even in situations of him willing to cooperate, as a matter of practice, his evidence needs corroboration. This is despite the fact that under section 133 of the Evidence Act 1950, an accomplice shall be a competent witness against an accused person and a conviction is not illegal merely because it proceeds upon the uncorroborated testimony of an accomplice. Although in practice, testimony by 
INTERNATIONAL JOURNAL OF ACADEMIC RESEARCH IN BUSINESS AND SOCIAL SCIENCES Vol. 8, No. 11, Nov, 2018, E-ISSN: 2222-6990 @ 2018 HRMARS

an accomplice is admissible, at the end of the day, it has to reach the standard proof of beyond reasonable doubt in convicting an offender based solely on the testimony of an accomplice. Therefore as a matter of practice, testimony by an accomplice with corroboration is preferable. Without corroboration, conviction is difficult (though not impossible) to be secured. According to Omar, Marimuthu and Mahali (2014) the rationale for treating accomplices with suspicion is because he has an obvious interest in diverting blame from himself to the person against whom he testifies. The Federal court viewed in the case of Tan Boon Soon v PP, I ML 219 (1966) that an accomplice has an obvious interest in currying favour with the authorities in whose hands his own fate lies. Hassan Lah, (2008) Judge of Court of Appeal, in the case of Chong Chee Liong v PP gave reasons why the evidence of an accomplice is not reliable. In quoting Sarkar on Evidence (14 $\left.{ }^{\text {th }} \mathrm{edn}\right)$ at -1924 , he stated that:

The principle reasons for holding accomplice evidence to be untrustworthy are: (1) because an accomplice is likely to swear falsely in order to shift the guilt from himself; (2) because an accomplice being a participator in crime, and consequently an immoral person, is likely to disregard the sanction of an oath; (3) because an accomplice gives his evidence under the promise of pardon, or in the expectation of an implied pardon; if he discloses all he knows against those whom he acted criminally, and this hope would lead him to favour the prosecution .

Both problems could arise in crimes committed by gangs known as secret society. A number of incidents were reported by Minister of Home Affairs, Noh Mohammad (as he was then) in the Parliamentary debate on amendment to POCA. Incident number one occurred on the $4^{\text {th }}$ of July 2013 at about 6 pm in Batang Kali, Hulu Selangor, at the Shell petrol station, Geng 36 attacked Geng 08. One victim dies. Five men were suspected, but no further action is taken due to the problem in finding a reliable witness. In another incident, on the 22nd of March at Opposie Hardware shop, Seri Semarak Marketing Sdn. Bhd, No. 18, Selayang Baru, 10 Batu Caves, Selangor. Geng 24 attacked Geng 36. One died, and four injured. 12 men were suspected however further action could not be taken as no other credible witness available. Recently, the problem caused by secret society had shocked the Malaysian nation, when a man, murdered at Johor Baru petrol station on 17 of July 2017 which went viral, was identified as a 'kongsi gelap' (secret society) leader (Abas, 2017).

Another example was highlighted by an Inquiry Officer in an interview conducted at Public Safety and Security Department, Ministry of Home Affairs in Putrajaya. When a man was arrested for possession of a stolen motor vehicle and he admitted stealing together with another man but to charge him with theft of a motor vehicle; there is no evidence of stealing. The most possible charge is offence of possession of stolen property punishable up to maximum five years of imprisonment. Under normal procedures, only him could be sentenced based on the available proof. What happens to another accomplice, who abetted him in the commission of the crime? The prosecutor may not have sufficient evidence to prosecute him under Penal Code. As an alternative, by applying POCA, the accomplice could be charged and sentenced accordingly.

Another situation supporting the advantages of crime control under POCA is an inability to prosecute an offender due to fear of the witness to testify against him. Under normal procedure, if a case depends solely on the eye-witness, the refusal of the witness to come forward and testify against the accused would be a hindrance to justice. However, the situation would be different, when the case 
is channeled through the preventive law. In ensuring those who are guilty punished accordingly, as well as to avoid future crimes, the application of POCA could be very significant. The report on the investigation by the police will be submitted to the Inquiry Officer, who will inquire and verify the accuracy of the said report. In doing so, Inquiry Officer is granted with enormous powers as stated in the POCA and POTA. These powers are:

a) To procure and receive all such evidence in any form and whether the evidence is admissible or not under any written law for the time being in force relating to evidence or criminal procedure which he may think necessary

b) To summon and examine any witness

c) To require for production of any document or other thing

d) if he considers it necessary in the public interest or to protect a witness, receive evidence in the absence of the person who is the subject of the inquiry provided the Inquiry Officer shall communicate the substance of the evidence, so far as the Inquiry Officer may consider it compatible with the public interest or to protect a witness

e) neither the person who is the subject of an inquiry nor a witness at an inquiry shall be represented by an advocate and solicitor except when his evidence is being taken and recorded by an Inquiry Officer

Therefore, the power to examine the witness without the presence of the person who is the subject of an inquiry could be done, and information could be obtained to search for the truth. Based on the evidence before him, it is the duty of the Inquiry Officer to deliberate its reliability and make a recommendation to the Board. According to an Inquiry Officer (based on an interview), when facing evidence by an accomplice, mere confession is still not sufficient to satisfy his inquiry. To become reliable, other supporting evidence is important though it may not be sufficient. Take for example in the case of theft of motor vehicle mentioned earlier, the existence of CCTV showing two persons committing the offence could be relevant and to prove involvement, evidence of communication through electronic means such as handphone would satisfy the Inquiry Officer as to the involvement of the accomplice (it is to be noted that in case where the identity of both could be identified from the CCTV, its no longer a case for preventive laws because the available evidence now favour the prosecution, to proceed trial in court of law). Eventually, the Inquiry officer will submit his report whether there are sufficient grounds for believing that the person who was the subject of an inquiry is a member of any of the registrable categories to the Board of POC consisting at least three members for final decision.

The Board will make a decision whether there are sufficient grounds for believing that the person is a member of any registrable categories. Upon their finding, that there are sufficient grounds, the Board will direct the Registrar of Criminal to enter his name in the and other particulars in the Register of Criminals. Upon entering his name in the register, if the Board is satisfied that it is necessary that control and supervision be exercised over the registered person but not necessary to detain him, direct that the registered person be put under police supervision for a period not exceeding five years and may renew such order for a period not exceeding five years at a time.

The Board may also direct that the registered person be detained under a detention order for a period not exceeding two years. The Board may renew such detention order for another period not exceeding two years if it is satisfied that such detention is necessary in the interest of public order. 
INTERNATIONAL JOURNAL OF ACADEMIC RESEARCH IN BUSINESS AND SOCIAL SCIENCES

Vol. 8, No. 11, Nov, 2018, E-ISSN: 2222-6990 @ 2018 HRMARS

\section{Electronic Monitoring Device and its Advantages}

The order of being subject to police supervision means the person is released with certain conditions including the requirement to be attached with EMD. Depending on the severity of the offence, the Board may also impose a condition for the person to be house curfew at certain hours. The application of EMD in this circumstances serves as a tool for monitoring by the police. In ordinary cases other than preventive laws, the duty of supervision is carried out by way of, random visit, random call and the accused self-reporting to the police station. However, in POCA and POTA, the mode of monitoring is enhanced by having the EMD attached to the person's body. This EMD is connected to the monitoring unit for twenty-four hours, and any sign of breach of any condition on EMD will alert the police officer's in charge through the short message system (SMS).

As a result, there are advantages in the application of EMD as a tool for monitoring of offenders. Any sign of breach of conditions on police supervision will reach the relevant authority immediately, and necessary action can be taken to remedy the violation. This inevitably contributes to the goal of controlling crime. The advantages of having EMD is also in line with the benefits of POCA and POTA since EMD at this point only applicable for persons arrested under the preventive laws. Its first operation started in August 2015 (Bernama, 2016).

\section{Fundamental Liberty}

Despite the benefits of EMD as a tool for crime control, EMD may attract fundamental issues. The discussion on possible issues not only relates to EMD but also the procedures leading to the order of attachment of EMD under POCA and POTA. The impact of preventive laws on liberty is not unexpected, as Article 149 of Federal Constitution clearly provides as such. This Article empowered the Parliament to enact laws to maintain the public order. Any provision of law, designed to stop or prevent that action is valid notwithstanding that it is inconsistent with any of the provisions of Article 5. 9. 10 or 13, or would apart from this Article be outside the legislative power of Parliament. Since preventive laws were promulgated under Article 149, consequently certain fundamental liberties are not in operation when laws are enacted to prevent the commission of any act prejudicial to the public order.

Issues which may relate to electronic monitoring by way of tagging is first, the right to privacy. For example, Plachta (2016) stated that alternatives to detention could also infringe the right to liberty and human rights impacts of their extended use must also be considered, especially with regard to electronic monitoring and house arrest. In addition, Gopalan and Bagaric (2016) viewed that the problem of infringement of privacy is among objections raised for the deployment of electronic monitoring (especially when accompanied by CCTV monitoring) as a sanction in lieu of jail. In the study by Maes and Mine (2013), although electronic monitoring is cost-effective, it is also a more restrictive, more invasive of privacy, a greater affront to dignity than any of the other alternatives to detention. The GPS must be charged for several hours a day, which means that participants in the program, have to plug themselves into the wall, constraining their movement for hours at a time. This can be degrading and dehumanizing experience (Marouf, 2017).

Federal Constitution of Malaysia does not contain express provision on the right to privacy. Nevertheless, to support the privilege of privacy, the discussion on the right to life would be significant. Article 5(1) provides no person shall be deprived of his life or personal liberty save in 
accordance with law. In elaborating the right to life, the Indian Constitution of Article 21 (in pari materia with Article 5(1)) would be referred to. Indian Supreme Court in Maneka Gandhi AIR SC 597 (1978), viewed that the words 'life' and 'liberty' be given extended meaning and inclusive of the right to human dignity and the right to privacy. The decision of Supreme Court of India in Maneka Gandhi's (1978) case and cases after it have asserted two important principles. Firstly, the Supreme Court has asserted that to treat as a fundamental right; it is not necessary that it should be expressly stated in the constitution as a fundamental right. Changes in politic, social and economy of the country entail the recognition of new rights. The law in its eternal youth grows to meet the demands of the society. Secondly, Article 21 was given the extended view and proven to be multidimensional. This multidimensional of Article 21 has been made possible by courts giving an extended meaning to the word 'life' and 'liberty' in Article 21. These two words according to Jain (2010), are not to be read narrowly, these are organic terms which are to be construed meaningfully.

The right to 'life' has been liberally interpreted to mean something beyond mere survival and the mere existence or animal existence. Hence it includes all facets of life to make a person's life meaningful, complete and worth living. In the case of Francis Coralie AIR SC 746 (1981) , a grand step was taken by the court when it argued 'life' in Article 21 does not mean merely 'animal existence' but living with 'human dignity'. The court has given very extensive parameters to Article 21:

"But the question which arises is whether the right to life is limited only to protection of limb or faculty or does it go further and embrace something more. We think that the right to life includes right to live with human dignity and all that goes along with it, viz., the bare necessities of life such as adequate nutrition, clothing and shelter over the head and facilities for reading, writing and expressing oneself in diverse forms, freely moving about and mixing and mingling with fellow human beings. Of course, the magnitude and content of the components of this right would depend upon the extent of the economic development of the country, but it must, in any view of the matter, include the right to the basic necessities of life and also the right to carry on such functions and activities as constitute the bare expression of the human self."

Another broad formulation of the theme of life with dignity is to be found in the case of Bandhua Mukti Morcha AIR SC 2218 (1997). Characterizing Article 21 as the heart of fundamental rights, the court gave it an expanded interpretation:

“...to live with human dignity, free from exploitation. It includes protection of health and strength of workers, men, and women, and of the tender age of the children against abuse, opportunities and facilities for children to develop in a healthy manner and conditions of freedom and dignity; educational facilities, just and human conditions of work and maternity relief. These are the minimum conditions which must exist in order to enable the person to live with human dignity. No government can take any action to deprive a person of the enjoyment of these basic rights."

This extended and broad approach to the word life to include the right to livelihood was adopted in the Malaysian case of Tan Tek Seng v Suruhanjaya Perkhidmatan \& Anor 1 ML 261 (1996). Gopal Sri Ram JCA cited:

“...the expression 'life' does not refer to mere existence. It incorporates all those facets that are an integral part of life itself and those matters which go to form the quality of life. Of these are the rights to seek and be engaged in lawful and gainful employment..." 
Balasingam and Bhatti (2017) commented that the Malaysian Constitution is an evolving document, it would be silly to suggest that the rights enshrined in it are set in stone; unable to adopt to modernday requirements. In concluding the evolution of Malaysian Constitution, the authors quoted the statement by Raja Azlan Shah LP (as his Royal Highness then was) opined on behalf of the Federal court in the case of Dato Menteri Othman bin Baginda \& Anor v Dato Ombi Syed Alwi bin Syed Idrus I ML (1981) that the constitution should be interpreted broadly. Sri Ram (2017) has also summed up; "The dynamics of constitutional interpretation changes as we acquire more knowledge about how we must approach our Constitution. We have moved away from looking at the Supreme Law as a last will and testament to an organic instrument that is constantly developing to meet new challenges to the Rule of Law and constitutional disobedience. In relation to Part 11 courts have moved away from the literal approach to the generous to the prismatic."

This extended meaning of the word 'life' and dynamic interpretation of provisions in the Federal Constitution, could suggest that right to privacy should be included as part of the meaning of life. The Supreme Court in the case of R. Rajagopal v. State of Tamil Nadu AIR SC 264 (1995) has averred that in recent times the right to privacy has received constitutional status; it is "implicit to the right to life and liberty guaranteed to the citizen." It is a "right to be left alone." A citizen has a right "to safeguard the privacy of his own, family, marriage, procreation, motherhood, child bearing and education among other matters".

The right to privacy protects a person's right to control the dissemination about himself. There are several types of privacy as stated by Ahmad (2008). The physical privacy means free from intrusion or observation that are unwanted. Informational privacy is the ability to control the conditions under which personal data is released. Psychological privacy is the control over released or retention of personal information to guard one's cognitions and impacts. Interactional privacy is relevant to a relationship in society as it ensures meaningful communication between persons and among members of the group.

A person who is subject to electronic monitoring by way of tagging may raise the issue of privacy from the aspect of information. The data collected through the monitoring by means of police supervision may be used not only to gain information related to the crime but other unnecessary purposes. Furthermore, the personal data obtained by the government is not governed by the Personal Data Protection Act 2010. It is also relevant to see when the body which is appointed to triangulate the data by way of GPS is a company appointed after securing a contract with the government. In cases of hacking of the system, which body would be accountable?

Consequently, the attachment of EMD to a body of a person infringes right to life from two aspects, i.e., right to privacy and human dignity. Firstly, right to information privacy on the data gathered out of monitoring. Secondly, the right to uphold dignity if the size of the electronic monitoring device is not compatible with humane since electronic monitoring device comes in different type and sizes.

\section{Natural Justice}

Next issue which may be relevant in the application POCA and POTA generally and EMD specifically is justice. It is a recognized that justice is an ultimate goal of every legal system. Nevertheless, justice is subjective, and a decision may be just to a person but not to another. Even the meaning and concept of justice varies. Meanwhile natural justice is an English common law concept developed in 
the $19^{\text {th }}$ century to create fair procedures in the face of increasing state power (Harding, 1981). Lucas (1980) stated the rule of natural justice are rules of procedure manifesting our concern for the individual, and our rational reluctance to do him down except for a good cause, which shall show not only that the action should be done but that the individual concerned is the one who should bear the brunt. In 2004, Jayakumar, viewed the current use of phrase 'natural justice' denotes the principles of fairness, i.e., the rule against bias and the requirement of fair hearing. A question may arise whether the procedures in POCA and POTA is line with natural justice. For example, in 2017, Kwang commented that though POTA appears to depart from the basic demand for a good valid reason for the continued holding of terror suspects, the methods and the procedural aspects set up in the POTA 2015 , breaks the spirit of the established criminal rules and procedures.

The non application of the ordinary criminal procedures in POCA and POTA was already explained at the early part of this paper. In summary, the initial investigation of an offence is the duty of the police and under POCA and POTA if the police has reason to believe that grounds exist which would justify the holding of an inquiry into the case of the person, arrest him without a warrant. Upon an arrest, the case shall be referred to the Public Prosecutor for direction not later than seven days from the date of arrest. The arrested person shall be taken without unreasonable delay, and in any case within twenty-four hours (excluding the time of any necessary journey) before a Magistrate. The arrested person may be remanded for twenty-one days on production of a statement in writing signed by a police officer, not below the rank of an Inspector stating that there are grounds for believing that the name of that person shall be entered on the Register of Criminal. A second application for remand of thirty-eight days shall be granted on production of a statement in writing signed by the Public Prosecutor stating that in his opinion sufficient evidence exist to justify the holding of an inquiry into the case.

The involvement of a legal officer namely the Public Prosecutor (or Deputy Public Prosecutor) started at the early stage of the first remand ( 21 days). Investigation Paper must be submitted to the Public Prosecutor, to determine whether the case is appropriate and applicable under the said preventive laws. The Investigation Paper consists of information and evidence relating to the arrested person's conduct will be deliberated to justify the holding of an inquiry. At the inquiry stage, the Inquiry Officer who must not be a police officer will conduct a second investigation on that person's case before making a recommendation to the Board. At this stage, the role of Public Prosecutor continues to assist the Inquiry Officer as to the legal aspect of the case. Finally, the Board (appointed by the Royal Highness), consists of members with legal and enforcement background, will be the final adjudicator. Notably, in the above procedures, there is no proper hearing conducted as enshrined under Article 10 of Universal Declaration of Human Rights in which 'Everyone is entitled in full equality to a fair and public hearing by an independent and impartial tribunal, in the determination of his rights and obligations and of any criminal charge against him'. Nonetheless, the arrested person is accorded with an opportunity to defend himself, firstly during inquiry process and secondly, on appeal to the court of law for judicial review. In addition, the right to be represented by counsel is present starting from the date of his arrest until the end of his case inclusive of appeal. Furthermore, the appointment of Board members by the YDPA, will ensure independence and impartiality of the decision made. In a nutshell, the element of check and balance in the above procedures is provided to uphold justice 
INTERNATIONAL JOURNAL OF ACADEMIC RESEARCH IN BUSINESS AND SOCIAL SCIENCES

Vol. 8, No. 11, Nov, 2018, E-ISSN: 2222-6990 (C) 2018 HRMARS

to an accused. This is to avoid as far as possible, wrongful conviction of an innocent and wrongful acquittal of a guilt.

\section{CONCLUSION}

The application of EMD for offenders under preventive laws serves as a tool to assist the authority in controlling crimes. There are procedures prescribed for the fitting of an EMD to a body of an offender under the respective Acts. Although aiming at controlling crime, there is still an element of due process in the procedures prescribed in POCA and POTA to avoid wrongful conviction of the innocents. The process could be said to be tedious and proper attention is accorded at every stage of the procedures. It is not a process whereby a person is arrested and attached with EMD or dumb into jail for a certain period, without due investigation. In summary, the application of EMD to a body of a person, indicates an advancement in the manner of controlling crimes. Nevertheless, there is still room for consideration and improvement to also include provision relating to the administration of data obtained by way of EMD.

\section{Acknowledgement}

This research is supported by the Malaysian Ministry of Higher Education and Universiti Teknologi MARA under the Fundamental Research Grant Scheme (FRGS) 600-IRMI/FRGS 5/3 (58/2016).

\section{Corresponding Author}

Haidar Dziyauddin

Faculty of Law, Universiti Teknologi MARA, Shah Alam, Selangor, Malaysia

Email: haidar@salam.uitm.edu.my

\section{References}

Abas, A. (2017, December 19). Man murdered at JB petrol station was secret society leader: DPM. The News Straits Times. Retrieved from https: www.nst.com.my/news/crimecourts/2017/12/316017/man-murdered-jb-petrol-station-was-secret-society-leader-dpm

Ahmad, N. (2008). The Right to Privacy and Challenges: A Critical Review. Malayan Law Journal Articles, $5 \mathrm{MLJ}$ cxxi.

Balasingam, U., and Bhatti, S.Q.Q.S. (2017). Between Lex Lata and Lex Perenda: An Evaluation of the Extent of the Right to Privacy in Malaysia. Malayan law Journal Articles, $4 \mathrm{ML}$ xxix

Bandhua Mukti Morcha v. Union of India AIR SC 2218 (Supreme Court 1997)

Bernama, (2016, February 25) Tiada Siapa boleh lepaskan diri daripada EMD' - Sinar Online.

Retrieved from https:www.sinarharian.com.my/

Chong Chee Liong 2 AMR 309 (2008) 2 MLJ 797 (2008).

Francis Coralie v Administrator, Union Territory of Delhi, AIR SC 746 (Supreme Court 1981)

Gopalan, S., and Bagaric, M. (2016). Progressive Alternatives to Imprisonment in an Increasingly Punitive (and Self-Defeating) Society Seattle University Law Review, 40 Seattle U. L. Rev 57. Harding, A.J. (1981) Natural Justice and the Constitution. Malaya Law Review 23 Malaya L. Rev. 226 Jain, M. (2010). Indian Constitutional Law (6th Ed.). Butterworths Wadhwa Nagpur: Lexis Nexis 
INTERNATIONAL JOURNAL OF ACADEMIC RESEARCH IN BUSINESS AND SOCIAL SCIENCES

Vol. 8, No. 11, Nov, 2018, E-ISSN: 2222-6990 @ 2018 HRMARS

Jayakumar, N.K. (2004). Lectures in Jurisprudence (2 ${ }^{\text {nd }}$ ed.). Butterworths, Wadhwa Nagpur: Lexis Nexis.

Kwang, H.P., Sabaruddin, J.S., \& Dhanapal, S. (2017). The Impact of Anti-Terrorism Law and Policy on Criminal Justice System: A Case Study in Malaysia, Malayan Law Journal Articles 5 MLJ Ixxxvi.

Lucas, J.R. (1980). On Justice. Oxford: Clarendon Press.

Maes, E., \& Mine, B. (2013). Some Reflections on the Possible Introduction of Electronic Monitoring as an Alternative to Pre-Trial Detention in Belgium, The Howard Journal of Criminal Justice. Doi:10.1111/hojo.12008

Malaysia. House of Representatives. Parliamentary Debates. (2013 October 2) Vol 13 pg 87 (Ahmad Zahid bin Hamidi)

Malaysia. House of Representatives. Parliamentary Debates. (2013 October 2) Vol 13 pg 94 (Ahmad Zahid bin Hamidi)

Malaysia. House of Representatives. Parliamentary Debates. (2013 October 2) Vol 13 pg 136 (Noh bin Omar)

Maneka Gandhi v. Union of India AIR SC 597 (1978)

Marouf, F.E. (2017). Alternatives to Immigration Detention, Cordozo Law Review, 38 Cordozo L. Rev. 2141.

Omar, H., Marimuthu, S. B.,\& Mahali, M. (2014). Law of Evidence in Malaysia, Selangor, Malaysia:Sweet \& Maxwell.

Packer, H. L. (1964). Two Models of The criminal Process. University of Pennsylvania Law Review Vol 113( November 1964 No. 1).

Plachta, M. (2016) European Union and Fair Trials Take-up a Problem of Pre-trial Detention, International Enforcement Law Reporter, 32 No 7

Ram, G.S. (2017). The Dynamics of Constitutional Interpretation. Malayan Law Journal Articles, 4 MLJ 1

R. Rajagopal v. State of Tamil Nadu AIR 1995 SC 264 (Supreme Court 1995)

Tan See Boon v PP, 1 MLJ 219 (1966).

Tan Tek Seng v Suruhanjaya Perkhidmatan \& Anor 1 MLJ 261, (Court of Appeal 1996) 